\title{
Ambidextrous Strategies and Innovation Priorities: Adequately Priming the Pump for Continual Innovation
}

\author{
Nehemiah Scott
}

\author{
" Plans are nothing. Planning is everything." \\ Dwight D. Eisenhower \\ 34th President of the United States
}

\begin{abstract}
The dynamic and unpredictable nature of the market has caused many organizations within rapidly changing industries to fail. These failures are, in part, due to a lack of continual and balanced innovation that firms should aim to achieve. That is, although firms may succeed at either refining existing competencies for incremental innovations or exploring new opportunities for radical innovations, many firms have experienced great difficulty in simultaneously pursuing and realizing success in both areas. This innovation imbalance arises when firms stick to traditional strategic notions of competition in fast-moving industries; these firms have not realized that the ability to compete in current and new markets begins with the strategies and priorities that are responsible for the very nature of innovation capabilities. The purpose of this study is to offer a reconceptualization of notions related to organizational strategy that are responsible for driving innovation capabilities. Specifically, this study develops a continual innovation framework that illustrates the impact ambidextrous strategies and priorities have on the firm's ambidextrous innovation capability. It offers a modified concept of ambidexterity (i.e., exploration, exploitation, coordination) to reconceptualize business, marketing, and information-systems strategies as ambidextrous strategy constructs. The article also discusses the relationships between constructs and the implications of this reconceptualization for researchers and managers.
\end{abstract}

\section{Introduction}

It was close to the end of his first term as President of the United States that President Dwight D. Eisenhower addressed the National Defense Executive Reserve Conference, and stated "Plans are nothing. Planning is everything." (Menon et al., 1999). Such a statement emphasizes that environmental volatility will render actual plans useless, but when good planning has been done upfront, plans become dynamic enough to circumvent such volatility. Such planning is necessary for firms wishing to compete within today's rapidly changing business environment. As market swings become more unpredictable, firms must make continual, timely, and appropriate changes to their products and processes (Bourgeois \& Eisenhardt, 1988; Chandrasekaran et al., 2012) to combat shorter product lifecycles, unsteady consumer demand, and greater product mix (Liu et al., 2012).
Despite the emphasis that has been placed on the role of innovation in firm competitiveness and survival, many firms have still failed to adapt partially or completely due to their inability to simultaneously pursue and succeed in existing and growth product markets (Davila \& Epstein, 2014). Whereas many studies focus on imbalance within the innovation capability itself (He \& Wong, 2004; Lin et al., 2013), this study argues that it is the planning activities comprised of strategies and innovation priorities prior to the actuation of the innovation capability that are most critical to ensure successful and timely innovation outputs. For example, a recent report by Accenture finds that manufacturers within the semiconductor industry experience difficulty in competing in traditional and new markets; this challenge is, at least in part, due to misalignments between organizational strategies and innovation priorities (i.e., business, IT and innovation strategies and priorities) that drive central innovation capabilities (Accenture, 


\section{Ambidextrous Strategies and Innovation Priorities}

Nehemiah Scott

2013). IBM also has suffered from lack of innovation planning; although they were the first to commercialize the router and multiple Internet-enhancing technologies, Cisco Systems and Akamai became market leaders in those segments, respectively (O'Reilly III et al., 2009). IBM was unable to capitalize on its head start because of inadequate pre-innovation strategies and innovation priorities, as demonstrated by their preoccupation with satisfying the demands in their current product markets only and a business model that neglected to set innovativeness as a high priority (O'Reilly III et al., 2009).

This article suggests that a firm wishing to succeed in both existing and growth product markets should concentrate on developing their pre-innovation strategies to support ambidextrous business endeavours, which requires firms to modify antiquated strategies and conventional business notions. Without the ability to succeed in current and new markets, a firm risks losing customers and being replaced by rival firms (Schreuders \& Legesse, 2012). Thus, the purpose of this study is to reconceptualize those organizational strategies that are responsible for driving innovation. Specifically, this study modifies a concept of ambidexterity to reconceptualize business, marketing, and information systems strategies and innovation priorities necessary to achieve ambidexterity in a firm's innovation capability, and it develops a continual innovation framework that illustrates the impact these ambidextrous strategies and priorities have on the firm's ambidextrous innovation capability.

\section{Literature Review: Exploration, Exploitation, and Ambidexterity}

The concept of ambidexterity was first introduced in Duncan's (1976) seminal study, and it is grounded in the organizational learning literature stream because its functionality is based on two learning mechanisms: exploration and exploitation. Exploration can be defined as the "things captured by terms such as search, variation, risk taking, experimentation, play, flexibility, discovery, and innovation" (March, 1991). Stated another way, exploration is the search for new external knowledge and opportunities (Kristal et al., 2010) with the focus on producing radical change and enhancing the organization's ability to quickly adapt to market changes (Sarkees et al., 2010). On the other hand, exploitation includes things such as "refinement, choice, production, efficiency, selection, implementation, execution" (March, 1991). That is, exploitation is the employment and refinement of internal firm knowledge (Kristal et al., 2010) and operations that can allow the firm to realize incremental changes and achieve gains from existing markets (Sarkees et al., 2010).

Both exploration and exploitation play vital roles in innovation, which Subramaniam and Youndt (2005) argue are due to the intricacies of knowledge management processes used for distinguishing and using ideas, tools, and favourable circumstances to develop new or improved products or services. Andriopoulos and Lewis (2009) find these innovation processes to be important also for continual renewal of firm capabilities and organizational survival. Tushman and O'Reilly III (1996) support this assertion by stating that balancing exploration and exploitation is important for the enduring success of the organization. However, it is this exploration-exploitation dynamic that has been subject of much debate in the literature. Specifically, some researchers yield to the tradeoff perspective (Levinthal \& March, 1993; March, 1991). As the creator of this view, March (1991) believes that an organization cannot be strong in both explorative and exploitative capabilities due to the tensions that originate from their conflicting knowledge-management processes. Levinthal and March (1993) continue this argument by asserting that firms will choose to overinvest resources toward either exploration or exploitation. However, such an overinvestment would be detrimental to the firm; whereas over-exploration causes the firm to enter a cycle of failures due to the uncertainty that comes with new innovations (i.e., a failure trap), over-exploitation causes a firm to neglect new markets due to their continued success in their current markets (i.e., a success trap) (Levinthal \& March, 1993).

In contrast, proponents of the complementary perspective state that firms can excel in the pursuit of the both exploration and exploitation (O'Reilly III and Tushman, 2013; Kristal et al., 2010; Nemanich et al., 2007; O'Reilly III \& Tushman, 2004). Tushman and O'Reilly III (1996) state that such a balance is necessary in order for firms to survive ambidextrously. From this view, ambidexterity is defined as the simultaneous pursuit and balance of exploration and exploitation activities (Lubatkin et al., 2006) as a means to reap revolutionary and evolutionary change (Tushman \& O’Reilly III, 1996).

\section{Ambidextrous Organizational Strategies}

Strategy is defined as "the match between what a company can do (i.e., organizational strengths and weaknesses) within the universe of what it might do (i.e., environmental opportunities and threats)" (Collis \& 


\section{Ambidextrous Strategies and Innovation Priorities}

\section{Nehemiah Scott}

Montgomery, 2008). The most successful firms deploy strategies spanning current, emerging, and future product markets (O'Reilly III et al., 2009). However, research purports that many firms have single-market-focused strategies and cannot compete as desired. In other words, "the aggressive pursuit of [only] operational excellence and incremental innovation crowds out the possibility of creating breakthrough innovations [and vice versa]" (Davila \& Epstein, 2014). In regard to alleviating this problem, research has implied that strategies should be ambidextrous in nature and that such a strategy can increase innovation efficiency and the firm's protection against strategic rigidities (Beinhocker, 1999) due to its dynamic nature (O'Reilly III \& Tushman, 2008).

Innovations are made possible due to the knowledge they are based on, and therefore, attention must be given to those strategies that are responsible for determining how the firm will acquire, integrate, and utilize knowledge to prime the innovation pump of the business. These strategies consist of business, marketing, and information-systems strategies. While marketing and information-systems strategies guide a firm's major activities for knowledge processing, they are both driven by the business strategy. Therefore, a firm should adopt business, marketing and information-systems strategies that are balanced by exploratory and exploitative knowledge. Following existing ambidexterity research, the ambidextrous strategies in this study are comprised of both exploration and exploitation. However, contrary to extant research, this study has also introduced coordination as a dimension of ambidexterity.

Here, coordination represents the strategic mechanism that monitors exploration and exploitation activities, making sure that neither one is overemphasized and to ensure that resource allocation is not constrained (March, 1991). This dimension is important for two reasons. First, coordination is necessary for efficient resource utilization for ambidexterity. Regardless of whether a firm decides to implement separated exploration and exploitation into separate business units (O’Reilly III \& Tushman, 2004) or pursue ambidexterity within a single business unit (Gibson \& Birkinshaw, 2004), exploration and exploitation compete for resources (March, 1991), and these resources must be managed effectively if the firm looks to optimize the benefits of ambidexterity (O'Reilly III \& Tushman, 2013). In addition, coordination within and transcending firm boundaries is important. In fact, Raisch and colleagues
(2009) contend that "ambidextrous management requires firms to explore new knowledge, exploit existing knowledge, and coordinate these knowledge bases". Thus, ambidextrous innovation performance can be achieved when coordination of knowledge is transpiring between those areas of the firm where exploration and exploitation projects are housed and executed (Raisch et al., 2009; Tushman \& O’Reilly III, 1996).

\section{Conceptual Framework and Propositions}

As depicted in Figure 1, this study concerns ambidextrous firm strategies, innovation priorities, and subsequent innovation capabilities. It is contended that a firm's ambidextrous business strategy influences its ability to set ambidextrous strategic innovation priorities. Additionally, it is argued that a firm's ambidextrous business strategy and innovation priorities will influence the development of its ambidextrous marketing and information-systems strategies. Once these strategies are in place, the firm can position itself to build an ambidextrous innovation capability.

\section{Ambidextrous business strategy}

The business strategy of a firm serves as the competitive game plan that the organization will execute, in which the objective, scope, and goals will be outlined (Collis \& Rukstad, 2008). From here, an ambidextrous business strategy can be defined as the visionary and objective-seeking order of actions that details how the organization will simultaneously compete and succeed in current and growth product markets. When we think of traditional business strategy notions, three business strategy types developed by Miles and Snow (1978) can be used: defenders, prospectors, and analyzers. Whereas defenders avoid risk associated with radically innovative products and stress operational efficiency, prospectors seek to initiate industry change, encourage experimentation through heavy $R \& D$ investments, and accept greater risk linked to revolutionary products. Analyzers are a balance between prospectors and defenders, except that they are extremely risk averse (Miles \& Snow, 1978). In today's business environment, adopting one of these strategies will not allow a firm to keep up with industry competition and changing customer preferences (Markides, 2013). A firm must deploy an ambidextrous business strategy, which borrows concepts from these previously mentioned business strategy concepts. A firm adopting this strategy can develop plans that allows it to adapt to environmental changes and generate continual innovation ( $\mathrm{He} \&$ Wong, 2004; Gupta et al., 2006). 


\title{
Ambidextrous Strategies and Innovation Priorities
}

\author{
Nehemiah Scott
}

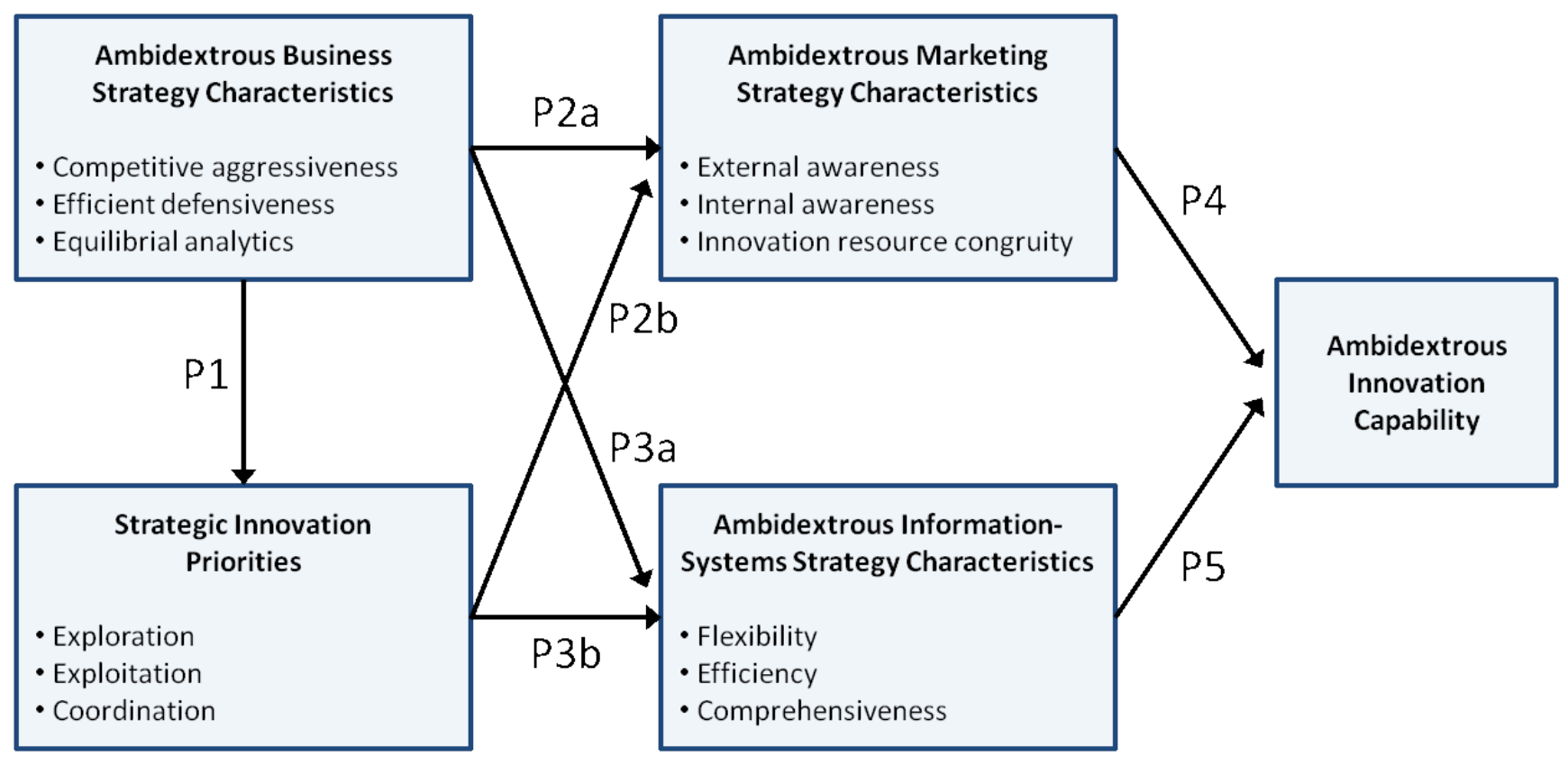

Figure 1. A continual innovation framework, with propositions about how a firm's ambidextrous strategies and priorities influence each other and the firm's ambidextrous innovation capability

In this study, an ambidextrous business strategy is characterized by competitive aggressiveness, efficient defensiveness, and equilibrial analytics. Competitive aggressiveness enables the firm to pursue exploration as a strategic innovation priority. Specifically, competitive aggressiveness demonstrates a firm's desire to invent new products, improve new product market returns, increase proactiveness via increased market scanning, and be adaptive through industry turbulence. On the other hand, exploitation can simultaneously be an innovation priority due to efficient defensiveness. Efficient defensiveness means the firm desires to achieve operational efficiency through economies of scale and cost-effective technology investments, while minimizing sales uncertainty by making incremental improvements to their current products (Sabherwal \& Chan, 2001). Lastly, coordination can be actuated due to equilibrial analytics. As an internally and externally driven characteristic, equilibrial analytics is concerned with how the firm makes use of analytical competencies to solve resource allocation tensions generated in balancing efforts related to competitive aggressiveness and efficient defensiveness. For example, a firm can use novel technologies, such as predictive analytics, to make proactive strategic decisions with regard to dividing future investments in long-term and short-term innovations (Venkatraman, 1989; Sabherwal \& Chan, 2001), thereby seeking to pursue exploration, exploitation, and coordination as key innovation priorities. As a result of the ambidextrous business strategy, these priorities mean that the firm intends to pursue ambidexterity throughout the innovation-management process. Thus, strategic innovation priorities should reflect this intention and should be comprised of exploration, exploitation, and coordination. Thus, the following is proposed:

\section{Proposition 1: An ambidextrous business strategy characterized by competitive aggressiveness, effi- cient defensiveness, and equilibrial analytics will enable a firm to successfully pursue exploration, ex- ploitation, and coordination as key strategic innov- ation priorities.}

\section{Ambidextrous marketing strategy}

An ambidextrous marketing strategy outlines the sequence of activities that will allow the firm to extend and exploit its resources for the exploration and attainment of the most significant market opportunities. Following traditional business logic, ambidextrous marketing strategy is driven by an ambidextrous business strategy, and is pertinent because dynamic markets are calling for a novel marketing approach to deal with the increasing levels of turbulence within the market (Matthyssens et al., 2005). 


\title{
Ambidextrous Strategies and Innovation Priorities
}

\author{
Nehemiah Scott
}

In this study, an ambidextrous marketing strategy is characterized by external awareness, internal awareness, and innovation resource congruity. External awareness is concerned with the rational and methodological consideration of the firm's external opportunities and threats, so that radically innovative outputs are adequately matched with environmental shifts (Bourgeois \& Eisenhardt, 1988). Thus, external awareness matches the external nature of exploration priority and seeks competitive aggressiveness business goals, such as greater new-product market returns and firm adaptability. On the other hand, internal awareness means that the firm will look to harness their internal strengths, minimize weaknesses, and incrementally modify the firm's marketing-related capabilities so that incrementally innovative outputs are adequate to handle minor external threats (Menon et al., 1999). Thus, internal awareness matches the internal nature of exploitation and exudes great focus on meeting efficient and defensive business goals, such as minimizing uncertainty in current product return and maximizing production efficiency. Lastly, innovation resource congruity can circumvent the issues that too much exploration and exploitation may cause. Resource congruity balances external and internal analytical decisions through cross-unit resource commitment meetings, where appropriate levels of human capital, time, and financial resources are allocated toward marketing activities, such as setting market performance goals and assessing the scale and scope of innovation (Menon et al., 1999), market experimentation, and product development. Resource congruity is driven by the coordination priority and equilibrial analytics, as it seeks to balance exploration and exploitation in innovationrelated marketing efforts. Thus, the following are proposed:

\section{Proposition 2a: A firm can successfully develop an ambidextrous marketing strategy characterized by external awareness, internal awareness, and innov- ation resource congruity if their ambidextrous busi- ness strategy is characterized by competitive aggressiveness, efficient defensiveness, and equilib- rial analytics.}

Proposition 2b: A firm can successfully develop an ambidextrous marketing strategy characterized by external awareness, internal awareness, and innovation resource congruity if exploration, exploitation, and coordination are their key strategic innovation priorities.

\section{Ambidextrous information-systems strategy}

One of the most pervasive aspects of information-systems research is to ensure that systems are aligned with the business strategy. In fact, relevant literature has firmly established the importance of strategic alignment (Tallon \& Pinsonneault, 2011; Tallon, 2007). Thus, following traditional business logic, an ambidextrous information-systems strategy is driven by an ambidextrous business strategy. Consequently, information-systems strategies are also critical to innovation, because they seek to develop the knowledge-handling capability of the firm (Zahra \& George, 2002) and ensure that knowledge can be fed to production and supply chain operations that support innovative efforts (Frohlich \& Westbrook, 2001).

An ambidextrous information-systems strategy is necessary to ensure that business demands spurred by radical and incremental innovation goals can be met by IT supply (Bot \& Renaud, 2012), and that the firm has the technology to acquire, store, analyze, integrate, and utilize knowledge in a way that is conducive to meeting such goals; such a strategy is characterized by flexibility, efficiency, and comprehensiveness (Sabherwal \& Chan, 2001). Flexibility means that the firm should be able to use their system for acquiring and analyzing externally-generated knowledge related to future innovations from external stakeholders. Although this notion seems like "old news", many established firms still use out-of-date systems and face challenges in gearing up for future product innovations. For example, whether a firm can collect data from active consumers by integrating their system with technologies such as smartphone location and video feed applications can help determine their success or lack thereof in radical innovations (Rao, 2009). On the other hand, efficiency means that the firm can use their operational support systems to monitor daily operations with regard to current products, assess operational efficiency (Sabherwal \& Chan, 2001), and analyze ways of increasing productivity and profitability via incremental process innovation. An example of such efficiency benefits comes from the manufacturing industry, with firms such as General Electric and Siemens installing sensors to help them predict when machine maintenance is needed so that unplanned maintenance costs can be minimized (Buytendijk, 2013). This approach satisfies exploitation as an innovation priority and efficient defensiveness as part of the business strategy.

Lastly, comprehensiveness means that the external and internal technology structures can easily be integrated so that the firm can balance short-term incremental 


\section{Ambidextrous Strategies and Innovation Priorities}

\section{Nehemiah Scott}

and long-term radical innovations across their partnership network. For example, technology manufacturers adopting enterprise resource-planning systems alongside predictive analytics software are positioned to realize greater operational and strategic performance because their strategic partners are aligned with their innovation needs. Thus, comprehensiveness balances flexibility and efficiency, and it also facilitates planning for current and future product innovations at the firm and strategic-partnership levels, satisfying the equilibrial analytics goal of the business strategy. Thus, the following are proposed:

\section{Proposition 3a: A firm can successfully develop an ambidextrous information-systems strategy charac- terized by flexibility, efficiency, and comprehensive- ness if their ambidextrous business strategy is characterized by competitive aggressiveness, effi- cient defensiveness, and equilibrial analytics.}

\section{Proposition 3b: A firm can successfully develop an ambidextrous information-systems strategy charac- terized by flexibility, efficiency, and comprehensive- ness if exploration, exploitation, and coordination are their key strategic innovation priorities.}

As a result of pre-innovation ambidextrous marketing and information-systems strategies, the firm is in position to build appropriate strategic innovation capabilities. Specifically, it is contended that these strategies can enable a firm to build an ambidextrous innovation capability (Lin et al., 2013), which will enable the firm to stay competitive and survive the dynamic business environment on the basis of exploration, exploitation, and coordination. External awareness paired with flexibility in information systems can help the firm build a superior exploratory innovation capability that enables them to increase their flexibility and competitiveness in new product markets, thereby increasing revenues (Bot, 2012) and market share (Jansen, 2005). Internal awareness paired with efficient utilization of information systems enables the firm to build strong exploitative innovation capability, resulting in the firm performing well in their existing businesses and increasing profitability through greater operational efficiency (Cao et al., 2009; He \& Wong, 2004). Finally, innovation resource congruity paired with comprehensive information systems will allow the firm to control investment-allocation decisions in new product development with their strategic partners, allowing for continual innovations in both current and growth product markets. Thus, the following are proposed:

\begin{abstract}
Proposition 4: A firm can successfully develop an ambidextrous innovation capability if its ambidextrous marketing strategy is characterized by external awareness, internal awareness, and innovation resource congruity.
\end{abstract}

Proposition 5: A firm can successfully develop an ambidextrous innovation capability if its ambidextrous information systems strategy is characterized by flexibility, efficiency, and comprehensiveness.

\section{Implications and Conclusion}

There are a number of research and managerial implications that spur from this study. First, this study has developed concepts at a high level. Therefore, researchers can further develop them into concepts that can be operationalized and conduct an empirical investigation to test the propositions that have been posited in this study. From a practitioner standpoint, company leaders can utilize Figure 1 and the discussion of its concepts to assess whether their current firm strategies and priorities are geared toward ambidexterity and continual innovation. Thus, this study and its framework can be used to help firms reposition themselves if necessary and cultivate their innovation capabilities to withstand unforeseen industry changes, especially for firms operating in fast-moving industries.

This study concentrated on the development of those strategies and priorities that are critical for a firm pursing ambidexterity. This study contends that building ambidexterity into the pre-innovation business, marketing, and information-systems strategies from the outset, and setting ambidexterity as a key strategic priority, can enable the firm to build an ambidextrous innovation capability and position it to continually succeed in incremental and radical innovation product markets. As a result, this study makes several contributions to extant innovation research. First, this study modifies the concept of ambidexterity by adding coordination as a mechanism that balances exploration and exploitation. Secondly, this research reconceptualizes three organizational strategies as ambidextrous strategies necessary for innovation: i) a business strategy that emphasizes competitive aggressiveness, efficient defensiveness, and equilibrial analytics; ii) a marketing strategy that emphasizes external awareness, internal awareness, and innovation resource congruity; and iii) an information-systems strategy that emphasizes flexibility, efficiency, and comprehensiveness. 


\section{Ambidextrous Strategies and Innovation Priorities}

\section{Nehemiah Scott}

Altogether, this study emphasizes that a firm desiring the simultaneous accomplishments of incremental and radical innovations must be ambidextrous in business, marketing, and information-systems strategies and strategic priorities, and that failure to do so will render the firm unsuccessful.

\section{About the Author}

Nehemiah Scott is a PhD student in the Manufacturing \& Technology Management program in the College of Business and Innovation at the University of Toledo, USA. He holds a BS in Computer Science and Engineering Technology and an MBA specializing in Information Systems from the University of Toledo. He also has corporate experience in the field of information systems working as a database programmer, and he has research and consulting experience in the area of process improvement. Nehemiah's main research interests include innovation and technology management, and supply chain management. His past research focused on innovation in bottom-of-pyramid societies and the supply chain. His current research focuses on ambidexterity for firm innovation and adaptation.

\section{References}

Accenture. 2013. Semiconductor Supply Chains: An Urgent Need for Change. Ottawa: Accenture.

Andriopoulos, C., \& Lewis, M. W. 2009. Exploitation-Exploration Tensions and Organizational Ambidexterity: Managing Paradoxes of Innovation. Organization Science, 20(4): 696-717. http://dx.doi.org/10.1287/orsc.1080.0406

Beinhocker, E. D. 1999. On the Origin of Strategies. McKinsey Quarterly, (4): 46-57.

Bot, S. D. 2012. Process Ambidexterity for Entrepreneurial Firms. Technology Innovation Management Review, 2(4): 21-27. http://timreview.ca/article/547

Bot, S. D., \& Renaud, P. E. 2012. Process Ambidexterity for IT Entrepreneurship. Technology Innovation Management Review, 2(8): 2330.

http://timreview.ca/article/596

Bourgeois, L. J. \& Eisenhardt, K., 1988. Strategic Decision Processes in High Velocity Environments: Four Cases in the Microcomputer Industry. Management Science, 34(7): 816-835.

http://dx.doi.org/10.1287/mnsc.34.7.816
Buytendijk, F. 2013. The Art of Big Data Innovation. Financial Times, 11 July 2013. Accessed July 9, 2014: http://www.ft.com/cms/s/0/8ceff2f2-ea6f-11e2-913c-00144feabdc0.html

Cao, Q., Gedajlovic, E., \& Zhang, H. 2009. Unpacking Organizational Ambidexterity: Dimensions, Contingencies, and Synergistic Effects. Organization Science, 20(4): 781-796. http://dx.doi.org/10.1287/orsc.1090.0426

Chandrasekaran, A., Linderman, K., \& Schroeder, R. 2012. Antecedents to Ambidexterity Competency in High Technology Organizations. Journal of Operations Management, 30(1-2): 134-151. http://dx.doi.org/10.1016/j.jom.2011.10.002

Collis, D. J., \& Montgomery, C. A. 2008. Competing on Resources. Harvard Business Review, 86(7-8): 140-150.

Collis, D. J., \& Rukstad, M. G. 2008. Can You Say What Your Strategy Is? Harvard Business Review, 86(4): 82-90.

Davila, T., \& Epstein, M. 2014. The Innovation Paradox: Why Good Businesses Kill Breakthroughs and How They Can Change. San Francisco: Berrett-Koehler Publishers.

Duncan, R.B. 1976. The Ambidextrous Organization: Designing Dual Structures for Innovation. In R. Kilman and L. Pondy (Eds.), The Management of Organizational Design: 167-188. New York, NY: North Holland.

Frohlich, M. T., \& Westbrook, R. 2001. Arcs of Integration: An International Study of Supply Chain Strategies. Journal of Operations Management, 19(2): 185-200. http://dx.doi.org/10.1016/S0272-6963(00)00055-3

Gibson, C. B., \& Birkinshaw, J. 2004. The Antecedents, Consequences, and Mediating Role of Organizational Ambidexterity. Academy of Management Journal, 47(2): 209-226. http://dx.doi.org/10.2307/20159573

Gupta, A. K., Smith, K.E.N.G., \& Shalley, C. E. 2006. The Interplay Between Exploration and Exploitation. Academy of Management Journal, 49(4): 693-706. http://dx.doi.org/10.5465/AMJ.2006.22083026

He, Z.-L., \& Wong, P.-K. 2004. Exploration vs. Exploitation: An Empirical Test of the Ambidexterity Hypothesis. Organization Science, 15(4): 481-494.

http://dx.doi.org/10.1287/orsc. 1040.0078

Jansen, J. 2005. Ambidextrous Organizations: A Multiple-level Study of Absorptive Capacity, Exploratory and Exploitative Innovation, and Performance. Rotterdam: Erasmus University.

Kristal, M. M., Huang, X., \& Roth, A. V. 2010. The Effect of an Ambidextrous Supply Chain Strategy on Combinative Competitive Capabilities and Business Performance. Journal of Operations Management, 28(5): 415-429. http://dx.doi.org/10.1016/j.jom.2009.12.002

Levinthal, D. A., \& March, J. G. 1993. The Myopia of Learning. Strategic Management Journal, 14: 95-112. http://dx.doi.org/10.1002/smj.4250141009

Lin, H. E., McDonough, E. F., Lin, S. J., \& Lin, C.Y.Y. 2013. Managing the Exploitation/Exploration Paradox: The Role of a Learning Capability and Innovation Ambidexterity. Journal of Product Innovation Management, 30(2): 262-278.

http://dx.doi.org/10.1111/j.1540-5885.2012.00998.x 


\section{Ambidextrous Strategies and Innovation Priorities}

\section{Nehemiah Scott}

Liu, G. J., Shah, R., \& Babakus, E. 2012. When to Mass Customize: The Impact of Environmental Uncertainty. Decision Sciences, 43(5): 851-887.

http://dx.doi.org/10.1111/j.1540-5915.2012.00374.x

Lubatkin, M. H., Simsek, Z., Ling, Y., \& Veiga, J. F. 2006. Ambidexterity and Performance in Small-to Medium-Sized Firms: The Pivotal Role of Top Management Team Behavioral Integration. Journal of Management, 32(5): 646-672.

http://dx.doi.org/10.1177/0149206306290712

March, J. G. 1991. Exploration and Exploitation in Organizational Learning. Organization Science, 2(1): 71-87. http://dx.doi.org/10.1287/orsc.2.1.71

Markides, C. C. 2013. Business Model Innovation: What Can The Ambidexterity Literature Teach Us? Academy of Management Perspectives, 27(4): 313-323.

http://dx.doi.org/10.5465/amp.2012.0172

Matthyssens, P., Pauwels, P., \& Vandenbempt, K. 2005. Strategic Flexibility, Rigidity and Barriers to the Development of Absorptive Capacity in Business Markets: Themes and Research Perspectives. Industrial Marketing Management, 34(6): 547-554.

http://dx.doi.org/10.1016/j.indmarman.2005.03.004

Menon, A., Bharadwaj, S. G., Adidam, P. T., \& Edison, S. W. 1999. Antecedents and Consequences of Marketing Strategy Making: A Model and a Test. Journal of Marketing, 63(2): 18-40.

http://www.jstor.org/stable/1251943

Miles, R. E., \& Snow, C. C. 1978. Organizational Strategy, Structure, and Process, New York: McGraw-Hill.

Nemanich, L. A., Keller, R. T., \& Vera, D. 2007. Managing the Exploration/Exploitation Paradox in New Product Development: How Top Executives Define Their Firm'S Innovation Trajectory. International Journal of Innovation and Technology Management, 4(3): 351-374.

http://dx.doi.org/10.1142/S0219877007001132

O’Reilly III, C. A., Harreld, B. J., \& Tushman, M. L. 2009. Organizational Ambidexterity: IBM and Emerging Business Opportunities. California Management Review, 51(4): 75-100. http://dx.doi.org/10.2307/41166506

O’Reilly III, C. A., \& Tushman, M. L. 2004. The Ambidextrous Organization. Harvard Business Review: 74-81.

O’Reilly III, C. A., \& Tushman, M. L. 2008. Ambidexterity as a Dynamic Capability: Resolving the Innovator's Dilemma. Research in Organizational Behavior, 28: 185-206. http://dx.doi.org/10.1016/j.riob.2008.06.002

O’Reilly III, C. A., \& Tushman, M. L. 2013. Organizational Ambidexterity: Past, Present, and Future. The Academy of Management Perspectives, 27(4): 324-338. http://dx.doi.org/10.5465/amp.2013.0025
Raisch, S., Birkinshaw, J., Probst, G., \& Tushman, M. L. 2009. Organizational Ambidexterity: Balancing Exploitation and Exploration for Sustained Performance. Organization Science, 20(4): 685-695. http://dx.doi.org/10.1287/orsc. 1090.0428

Rao, H. 2009. Market Rebels and Radical Innovation. Mckinsey Quarterly, (2): 126-133.

Sabherwal, R., \& Chan, Y. E. 2001. Alignment between Business and IS Strategies: A Study of Prospectors, Analyzers, and Defenders. Information Systems Research, 12(1): 11-33. http://dx.doi.org/10.1287/isre.12.1.11.9714

Sarkees, M., Hulland, J., \& Prescott, J. 2010. Ambidextrous Organizations and Firm Performance: The Role of Marketing Function Implementation. Journal of Strategic Marketing, 18(2): 165-184. http://dx.doi.org/10.1080/09652540903536982

Schreuders, J., \& Legesse, A. 2012. Organizational Ambidexterity: How Small Technology Firms Balance Innovation and Support. Technology Innovation Management Review, 2(2):17-21. http://timreview.ca/article/522

Subramaniam, M., \& Youndt, M. A. 2005. The Influence of Intellectual Capital on the Types of Innovative Capabilities. Academy of Management Journal, 48(3): 450-463.

http://dx.doi.org/10.5465/AMJ.2005.17407911

Tallon, P. P. 2007. A Process-Oriented Perspective on the Alignment of Information Technology and Business Strategy. Journal of Management Information Systems, 24(3): 227-268. http://dx.doi.org/10.2753/MIS0742-1222240308

Tallon, P. P., \& Pinsonneault, A. 2011. Competing Perspectives on the Link Between Strategic Information Technology Alignment and Organizational Agility: Insights from a Mediation Model. MIS Quarterly, 35(2): 463-486.

Tushman, M. L., \& O'Reilly III, C. A. 1996. Ambidextrous Organizations: Managing Evolutionary and Revolutionary Change. California Management Review, 38(4): 8-30. http://www.jstor.org/stable/41165852

Venkatraman, N. 1989. Strategic Orientation of Business Enterprises: The Construct, Dimensionality, and Measurement. Management Science, 35(8): 942-962. http://dx.doi.org/10.1287/mnsc.35.8.942

Zahra, S. A., \& George, G. 2002. Absorptive Capacity: A Review, Reconceptualization, and Extension. Academy of Management Journal, 27(2): 185-203.

http://dx.doi.org/10.5465/AMR.2002.6587995 